\title{
Methodological approaches in the design of Smart Specialization Strategy in Serbia ${ }^{4}$
}

\author{
Article history: \\ Received: 13 March 2020 \\ Sent for revision: 20 May 2020 \\ Received in revised form: 5 June 2020 \\ Accepted: 10 June 2020 \\ Available online: 19 October 2020
}

\begin{abstract}
The aim of this paper is to present two methodological approaches to the analysis of the regional potentials in the Republic of Serbia as a first out of the six-step phases of the development of Research and Innovation Strategy for Smart Specialization (RIS3). Within the quantitative analysis of regional/national context, two approaches that have been used in order to select preliminary priority areas are Location Quotient (LQ) and Multi-Criteria Decision Making (MCDM). This paper presents discussions related to challenges of implementation of a methodology for selection of priority sectors in the economy based on the use of $L Q(L Q \geq 1.5)$ and use of MCDM methods for aggregation of all available indicators in order to be able to produce ranking lists of all active sectors in the Republic of Serbia. Both implemented methods are relatively simple. The use of the $L Q$ method is very useful in order to select a limited number of priorities, while the MCDM method is ideal for consolidating all available indicators into one indicator: forming a ranking list of all NACE sector groups in the region or country, with the precise position of each group.
\end{abstract}

Keywords: Smart Specialization; S3 Strategy; MCDM methods; Priority Sectors; Dialogue

\footnotetext{
${ }^{1}$ Institute Mihajlo Pupin, djuro.kutlaca@pupin.rs

2 Institute Mihajlo Pupin

3 Institute Mihajlo Pupin

${ }^{4}$ Research is supported by the Ministry of Education, Science and Technological Development of the Republic of Serbia.
} 


\title{
METODOLOŠKI PRISTUPI U KREIRANJU STRATEGIJE PAMETNE SPECIJALIZACIJE U SRBIJI
}

\begin{abstract}
Apstrakt: Cilj ovog rada je da predstave dva metodološka pristupa analizi regionalnih potencijala u Republici Srbiji kao prvom od šest koraka u razvoju Strategije istraživanja i inovacija za pametnu specijalizaciju (RIS3). U okviru kvantitavne analize regionalnog/nacionalnog okvira, dva pristupa su bila korišćena da bi se preliminarno selektovale prioritetne oblasti: koeficijent lokacije (LQ) i višekriterijumsko odlučivanje (MCDM). Ovaj rad predstavlja diskusije koje se odnose na izazove u primeni metodologije za izbor prioritetnih oblasti u privredi bazirane na korišćenju LQ (LQ $\geq 1.5)$ I MCDM metoda agregacije svih raspoloživih indikatora kako bi se omogućilo pravljenje ranglista svih aktivnih sektora u Republici Srbiji. Obe primenjene metode su relativno jednostavne za razumevanje i korišćenje; iako bi korišćenje MCDM (Idealne tačke) moglo biti korisnije, primenjujući geometrijsku distancu kao agregatnu meru za sve primenjene indikatore ekonomskog, inovacionog $\mathrm{i}$ naučnog potencijala.
\end{abstract}

Ključne reči: pametna specijalizacija, S3 Strategija; MCDM metode; prioritetni sektori, dijalog

\section{Introduction}

Smart Specialisation Strategy (S3) is a "policy concept" which theoretical roots integrate macroeconomic theories of growth with neo-Schumpeterian approaches to innovation theory, conceptualized into "science, technology, innovation and growth systems" (STIGS) as appropriate subjects for policyoriented research (Aghion et. al, 2009). Founders of the smart specialization approach insist on structural evolution as key process: "the discovery that drives the process of smart specialization is not about a simple innovation but generates knowledge about the future economic value of a possible structural change" and further "R\&D and innovation in a certain field have the potential to create activities that will be progressive and commercial attractive within the content of the regional economy, whereas previously they were not so". (Foray et. al, 2009). S3 is considered as a precondition for use of structural funds: "This Communication complements the one on the Innovation Union by calling on policymakers in the Member States at all levels to act without delay to invest more ... on smart growth" (European Commission, 2010). The role of S3 became more important and in September 2017 it is officially named as the new 
industrial policy for EU relying on the integration of R\&D and innovation with business: "Investing in a smart, innovative and sustainable Industry - A renewed EU Industrial Policy Strategy" (European Commission, 2017). S3 is addressed to regions rather than the country level in order to concentrate resources on a few key priority sectors (European Commission, 2010).

The S3 Platform is established by the JRC-IPTS (Joint Research CentreInstitute for Prospective Technological Studies) in Seville in order to provide member countries with various forms of support, e.g. in terms of seminars, trainings, peer review sessions and guidelines for the development of Research and Innovation Strategies for Smart Specialisation (RIS3).

Unlike EU member states, Western Balkan (WB) countries as associate or candidate countries for membership in the EU, are not obligated to have S3 as formal policy documents for economic development. The European Union's enlargement policy provides EU candidate countries with greater opportunities for economic transformation. The Instrument for Pre-Accession Assistance, which is regulated by an EU regulation (European Parliament and Council, 2014), defines smart specialization as a thematic priority for assistance for candidate countries. Therefore, S3 has a legal basis and it is relevant to both: EU members and candidate countries. (Radosevic, 2016). Therefore, although "not obligatory" document, S3 became the precondition for accession to the EU for all WB countries.

New EU strategy for the Western Balkans describes the ways of how to boost entrepreneurship and innovation in the region through technology transfer and start-up support (European Commission, 2018). The Science for Policy report by the JRC identifies key challenges and innovation potentials in the Western Balkan region and provides key tools to support this region in its economic transformation through smart specialization (Matusiak \& Kleibrink, 2018).

This paper primarily addresses issues related to challenges of implementation of the methodology for the development of S3, particularly identification/selection of priority sectors in economy based on use of Location Quotient (LQ) as it is proposed by the foreign experts engaged by the JRC (LQ $\geq 1.5$ ), and use of Multiple Criteria Decision Making (MCDM) methods for aggregation of all available indicators in order to be able to produce ranking lists of all active sectors in the Republic of Serbia.

The second chapter gives a review of methodological tools used by European regions in analyzing regional/national context. Chapter 3 describes the process of designing the RIS3 in Serbia. Chapters 4 and 5 show the main results of the quantitative analysis using two methodological approaches: LQ and MCDM, and finally chapter 6 draws key challenges to facilitate the design of smart specialization in Serbia and a set of conclusions. 


\section{Review of analysis of regional/national context in European regions}

In the process of designing RIS3, the first step is based on the analysis of regional or national economic, innovative and research potentials in order to identify key strengths and find the most competitive areas in the future. The main aim of analysing regional or national potential is to find new areas of application based on identified strengths and to find synergies between them not only locally but also globally (European Commission 2012).

The mapping of national/regional innovation systems is crucial for creating an evidence base for the detection of competitive advantages of nations/regions. In identifying priority areas of application, particular emphasis was given to empirical bases in most of the European regions and countries. There is no single method for identifying priority areas, it is recommended to use several different methods to obtain a clearer and more accurate overview of potential areas.

Several methods have been used by European regions in the last few years to identify the potential areas for smart specialization. According to Guide to Research and Innovation Strategies for Smart Specialisations (European Commission, 2012), the main relevant methods are the following:

- Analysis of (matching) Scientific and Technological specialization: analyses of specialization of R\&D investment, publications and citations, and patent applications and citations by 'field'.

- Analysis of regional economic specialization: quantitative analyses calculate degrees of specialization of regional economies on the basis of employment (or value-added) data.

- 'Cluster' in-depth case studies and peer reviews: to move beyond the figures that are available for comparison, more qualitative studies can be carried out on activity domains where a region shows relative specialization.

- Foresight: the aim of foresight is to capture existing expert intelligence sources on future trends and make them accessible for present decisionmaking.

In Slovenian RIS3, the empirical base was focused on international comparison of specific sectors and economic areas. In order to identify potential areas of specialization, technological specialization, export-related advantages, foreign investments, growth in productivity and export performance, were taken into account (Burger \& Kotnik, 2014). 
Several methods have been utilized to conduct the quantitative analysis in Romania in the context of establishing a Smart Specialisation Strategy. The methods used to identify potential areas for smart specialization included: an analysis of scientific and technological specialization, an analysis of regional economic specialization and cluster analysis (JASPERS/ARUP, 2013). Romanian South-East Development Region has conducted an empirical analysis that was based on economic and social indicators. As a result of the socio-economic analysis, areas that have the potential for smart specialization at the level of the South-East Development have been identified. These areas were discussed and analysed during the focus groups conducted at the regional level with relevant actors belonging to the quadruple helix (South-East Regional Development Agency, 2017).

In the Swedish Region Värmland, work on RIS3 included a review of existing economic analyses and research areas and the statistical analysis of the strong industrial sectors. These analyses provided the starting point for formulating potential priority areas but were considered robust because they were a combination of a competitive business community and outstanding research. They have conducted a business intelligence analysis in order to assess the international position of potential areas of specialization (Region Värmland, 2015). In the process of analysis of developing the regional innovation strategy, Region Skåne carried out a network analysis, functional analysis as well as an international peer review in order to identify the main weaknesses and strengths of the economic, innovation and research system of the region of Skåne. (European Commission, 2012). A review of the methods used in the main regions of Poland, showed a high variety of different methods that were used. The most commonly used methods are the following: desk research, statistic methods, SWOT analysis complemented by in-depth and focus group interviews (Gulc, 2015).

In the Kujawsko-Pomorskie Region, methods of identification of specialization niches were: foresight; analysis of the strongest regional economic areas and analysis of research and development potential. In the Opolskie region, in addition to foresight, discovery of key regional technologies, development areas, activities and groups have been used. (Czyzewska-Misztal \& Golejewska, 2016). The identification of smart specialization areas in the Lubelskie Voivodship Region was based on the bottom-up approach, combined with the self-assessment of economic, scientific, technological, educational and institutional potential. The analysis was performed in three dimensions: Scientific potential, through the identification of key research domains and disciplines; Educational, through the identification of key strengths in human resources; and Economic, through the discovering of the economic areas with the greatest potential The economic potentials were identified with the 
application of a location quotient (LQ) (Kociuba, 2015).Analytical evidencebase in Croatia was based on the several comprehensive evaluations conducted by OECD, World Bank (Aprahamian \& Guilherme Correa, 2015) as well as questionnaire surveys and several background studies. Analyses were based on the following factors: macroeconomic performance and productivity, business sector competitiveness, R\&D and innovation performance and potential of human capital and smart skills (Croatian Smart Specialisation Strategy 2016-2020, 2016).Mapping of regional/national scientific, economic and innovation potential is important for policymakers and stakeholders as a first step in designing the RIS3 in order to identify the main regional or national potentials, but also weaknesses and key challenges of the economy and the society. Approaches to creating evidence-based analysis in the European regions were diverse. It has been shown that the S3 concept could be implemented in all types of regions but specific methodologies and technique that were used depends on the available data and resources in the particular region or country

\section{Design of the Smart Specialisation Strategy in Serbia}

At the beginning of 2017, the Government of the Republic of Serbia has created an Inter-Ministerial Working Body (IWB) in order to develop a Strategy for Smart Specialization. The European Commission's JRC has supported these processes providing methodological and expert support. Analytical (AT) and operational team (OT) in Serbia were directly engaged to work on the development of RIS3, with support of the JRC. The OT was obliged to operationalize activities for the creation of RIS3 and communicate with major stakeholders. The AT was obliged to conduct quantitative and qualitative analyses necessary for building evidence-based decision making relevant for RIS3.

The S3 Platform has provided potential users with methodological advice on how to design national or regional RIS3 strategy in six steps (S3 Platform, 2012). In the process of preparatory activities, Serbia RIS3 team together with external support of the foreign experts (JRC and FhG ISI institute, Karlsruhe) has adopted the original methodological six steps in the development of the S3 into roadmap for development of RIS3 in Serbia in five phases originally planned to be realized in 2017-18 (JRC \& IWB, 2017):

Phase 1: Organisation of process of development of RIS3 in Serbia;

Phase 2: Mapping of economic, innovative and scientific potential at the regional level; 
Phase 3: Entrepreneurial discovery process for selected priority areas of smart specialization;

Phase 4: Development of a system for monitoring of implementation and expost impact evaluation of RIS3 in Serbia;

Phase 5: Organisation and financing of the implementation of RIS3 in Serbia.

Each European region is characterised by a specific context that determine the regions' ability to adopt a smart specialisation approach. These five phases are the result of the adaptation of the official RIS3 guideline to the context of Serbia and there were no significant deviations from the original steps.

Smart Specialization Strategy of the Republic of Serbia was adopted in February 2020. The process of its drafting encompassed roughly two stages: quantitative analysis and so-called "entrepreneurial discovery process” that included dialog with the relevant stakeholders. Quantitative analysis was performed by the Analytical Team who suggested that potential priority domains should be put in perspective with a view to several additional socioeconomic dimensions before publicly proposing them in a subsequent, stakeholder-based EDP (Kroll et al, 2017).

Mapping was a crucial, first step to identify preliminary priority domains and the relevant stakeholders for discussing them. The first stage has resulted in the identification of the potential priority domains for smart specialization. The analysis presented in this paper is based on them and the report created by the Fraunhofer Institute (Kroll et al, 2017). However, after the EDP process, the final list of the priorities domains for Smart Specialization in Serbia has been changed comparing to the quantitative analysis, identifying priority domains of the S3 as following at the national level: (1) Food for future (2) Information Communication Technologies (3) Machinery and production processes of the future and 4) Creative industries.

\section{Mapping of Economic, Innovative and Scientific Potential in Serbia}

Quantitative analysis of economic, innovation and scientific potential of the Republic of Serbia was carried out by a team of experts from the Fraunhofer ISI in Karlsruhe, with the support of the JRC and the analytical team in Serbia.

In order to map economic, innovation and scientific potential, a multidimensional quantitative analysis was used to identify NACE 3-digit groups at a regional level that have a comparative advantage over the national level. The data processed for quantitative analysis was provided by the Statistical Office 
of the Republic of Serbia, Intellectual Property Office and engaged domestic experts from the Analytical team.

Since 2011, Statistical Office of the Republic of Serbia recognizes the five major regions of Serbia: Region RS11: Belgrade; Region RS12: Vojvodina; Region RS21: Šumadija and Western Serbia; Region RS22: Southern and Eastern Serbia; (Region RS23: Kosovo - data are not available). Criteria used for selection of the priority sectors in regions was specialisation proper, measured by the Location Quotient (LQ) which compares for particular indicators (such as Employment, or Exports) the share of a sector in the region with the share of a sector in the country; threshold level was $L Q>1.5$ (formula 1 ; $e=$ sector $X$ employment in region, $\mathrm{E}=$ sector $\mathrm{X}$ employment in country, for NACE sector $\mathrm{X):}$

$$
L Q=\frac{\frac{e_{N A C E X}}{e_{\text {total }}}}{\frac{E_{N A C E X}}{E_{\text {total }}}}
$$

In addition, two more criteria were included: Absolute Size - This was an important and necessary criterion that is used because of the fact that the sector in a relative sense is more important than at the national level is irrelevant if in absolute terms is too small (for example: for indicator employment, one sector should be ignored, although LQ could be above 1.5 if employs only a few hundred people, if there are other sectors with similar LQ but with employment of several thousand people).

Growth - This criterion provided an answer to the question of whether the sector is growing or inherited in previous years, which would require efforts aimed at the economic transformation.

Quantitative analysis was based on the analysis of three sets of indicators:

(1) Indicators of Economic Potential:

- Employment - source: 2011-2016 Labour Force Survey (LFS) data, National statistical office;

- Employment - source: 2011-2016 Structural Business Statistics (SBS) data, National statistical office;

- Exports - source: 2012-2016 national export statistics, National statistical office;

(2) Indicators of Innovative Potential:

- Innovating firms - source: the 2010-2014 national innovation survey, National statistical office;

- Patents - source: indicators developed by the members of the Analytical team from the Mihajlo Pupin Institute, based on data provided by the Intellectual Property Office; 
(3) Indicators of Scientific Potential:

- Publications - source: indicators developed by the members of the Analytical team from the Faculty of Physics and Mihajlo Pupin Institute, based on data collected by the Faculty of Physics from the Web of Science (WoS), using WoS/Frascati classifications of fields of sciences.

The results of the mapping exercise produced a list of priority sectors for four statistical regions. The procedure for the selection of priority sectors was organized in several phases. Firstly, priority sectors for every single indicator of the economic, innovative and scientific potentials in analysed regions have been identified (Kroll et al., 2017).

The integration of all three analysed potentials was done in two steps using two thresholds levels ( $L Q>1.5$ and $L Q>1.25)$ for each indicator of economic, innovative and scientific potential. Excel file with integrated thresholds, selection criteria, and the step-by-step procedure is an analytical tool provided by external experts. The final table in this file consists of all NACE 3-digit sectors/groups with values $=1$ for sectors that fulfil conditions for selection of potential priority areas of specialization by regions, otherwise, this value is $=0$. Selection of the majority of the NACE 3-digit sectors/groups is based on value of $L Q>1.5$ for only one indicator from the sets of indicators of economic, innovation and scientific potentials, in three cases sectors are fulfilled these criteria for 2 indicators, and only in two cases sectors are fulfilled these criteria for 3 indicators, for total of 34 selections. Reducing this criterion to $L Q>1.25$, the situation is slightly improved, with four cases in which sectors are fulfilled this criterion for 2 indicators, and in three cases sectors fulfilled this criterion for 3 indicators, for a total of 50 selections (Kroll at al. 2017). A proposed threshold of $L Q>1.5$ for the selection of priority sectors is rigid but efficient, generating only a few sectors as priorities. The result of the described procedure has resulted in the selection of NACE 3-digit level sectors-groups by regions (LQ>1.5) presented in Appendix I.

As a final result of quantitative analyses, the following potential priority areas have been identified (Kroll at all, 2017):

RS11: Belgrade

- Computer Programming and ICT

- R\&D and Technical Consultancy

- Creative Economy

- Monetary Intermediation

Potentially emerging innovative 
- Beverages, Pharmaceuticals, Electrical Components, Transport Equipment

RS12: Vojvodina

- Automotive

- Agricultural Economy (including processing industries)

- Petrochemical Industry

- Plastics Industry

Potentially emerging, innovative, science:

- Agricultural Machinery, Measurement Instruments, Computer Science, Telecommunications

RS21: Šumadija and Western Serbia

- Agri-/Horti-/Silvicultural Economy (including processing industries)

- Automotive

- Textile Industry

- Plastics Industry

- Metal Industry

Potentially emerging, innovative, science:

- Special Purpose Machinery, (mechanical engineering, pharmacy)

RS22: Southern and Eastern Serbia

- Agri-/Horticultural Economy (including processing industries)

- Textile Industry

- Rubber Industry

- (Electrical Engineering)

Potentially emerging, innovative, science:

- Food Products, Medical and Dental (electrical engineering)

\section{Results of the MCDM methodology for S3}

With the aim of ranking preliminary priority sectors at the national level, taking into account all previously identified indicators and criteria, the multi-criteria ranking method was applied. A team from the Mihajlo Pupin Institute conducted a multi-criteria analysis based on the previous quantitative analysis in order to aggregate multiple criteria into one, single aggregate criterion. For this purpose, Compromise Programming Ideal Point Method (IPM) (Zeleny, 1976) has been 
implemented in the following way: a set of n NACE 3-digit sectors is compared with respect to $m$ indicators of economic, innovative and scientific potentials, and this comparison is conducted measuring distance of every NACE 3-digit sectors form an artificial sector which has ideal values for every indicator - we call this sector a reference sector.

A point in m-dimensional space of indicators represents each NACE 3-digit sector. The point representing the reference sector is referred to as the ideal sector, i.e. ideal point (this is the origin of the name of the applied method). The author of the Compromise Programming Ideal Point Method has recommended the use of geometrical distance $d$ of each NACE 3-digit sector from the reference/ideal, using formula (2) for calculation. The sector, whose distance from ideal is the shortest $(\mathrm{d}=\mathrm{min})$, is the best sector and the value of calculated distance $d$ is the value which could be used for the creation of a ranking list of NACE 3-digit sectors.

$$
\mathrm{d}_{\mathrm{i}}=\sqrt[1 / \mathrm{L}_{\mathrm{p}}]{\sum_{\mathrm{j}} \mathrm{k}_{\mathrm{j}} \times\left(\frac{\mathrm{IC} \mathrm{C}_{\mathrm{j}}-\mathrm{C}_{\mathrm{ij}}}{\left(\mathrm{C}_{\mathrm{ij}}\right)_{\max }}\right)^{\mathrm{L}_{\mathrm{p}}}} \quad ; \mathrm{j}=1, \ldots, \mathrm{m} ; \mathrm{i}=1, \ldots, \mathrm{n}
$$

Where:

ICj - a j-th single indicator for 'reference/ideal sector',

$\mathrm{Ci}, \mathrm{j}$ - a j-th single indicator of an i-th observed sector,

$\mathrm{kj}$ - a weighting factor of a j-th single indicator;

$\mathrm{j}$ - number of single indicators of economic, innovative and scientific potentials;

$\mathrm{i}$ - number of observed NACE 3-digit sectors;

Lp - used metrics,

$\mathrm{di}$ - calculated distance for i-th sector from the reference sector.

With $L p=2$, the formula is a calculation of Euclidean distance, and this case is used by the Analytical team.

Aggregating of all indicators of economic, innovative and scientific potentials into one, single criterion with MCDM Compromise Programming Ideal Point Method has resulted with generation of four complete ranking lists of NACE 3digit sectors active in four statistical regions in Serbia as well as with one ranking list for NACE 3-digit sectors which are active in entire country. In addition, not only the rank of the NACE 3-digit sector is available; there is the value of the distance from the reference sector as quantification of position in this rank list as well. For further work on preliminary priorities, we will only provide the ranking list of NACE sectors at the national level. The ranking list 
of the first 10 sectors formed using the multi-criteria ranking method is presented in Table 1. 
Table 1. Ranking list of NACE sectors-groups in Serbia total - first ten NACE 3-digit level sectors-groups, the year 2016

\begin{tabular}{|l|l|c|}
\hline $\begin{array}{l}\text { Ranking } \\
\text { Lists }\end{array}$ & NACE 3-digit Sectors - Groups - first ten presented & \\
\hline Rank 1 & NACE Sectors - Groups in Serbia total & Distance d \\
\hline 1. & J62.0 - Computer programming & 2.5704 \\
\hline 2. & M73.1 - Advertising & 2.7164 \\
\hline 3. & M71.1 - Architectural and engineering activities & 2.8321 \\
\hline 4. & A1.1 - Growing of non-perennial crops & 2.9523 \\
\hline 5. & G46.9 - Non-spec. wholesale trade & 2.9708 \\
\hline 6. & M71.2 - Technical testing and analysis & 2.9718 \\
\hline 7. & C28.2 - Manufacture of other general-purpose machinery & 2.9868 \\
\hline 8. & $\begin{array}{l}\text { C26.5 - Manufacture of instruments and appliances for } \\
\text { measuring, testing and navigation; watches and clocks }\end{array}$ & 2.9881 \\
\hline 9. & C10.8 - Manufacture of other food products & 3.0034 \\
\hline 10. & M72.1 - R \& D - Natural Science & 3.0075 \\
\hline
\end{tabular}

Source: Analytical team, internal working documents, 2017-2018

Comparing list of potentially priority areas of specialization by regions based on specialization proper, measured by the LQ and ranking list of NACE sectorsgroups generated using MCDM approach, it is clear that all priority areas identified on regional level with first approach (Appendix I) are placed within best-ranked sectors-groups using the second approach on national level (Table 1).

\section{Conclusions}

Generation of NACE 3-digit level priority sectors-groups for four statistical regions relied on the results of quantitative analysis which was based on the identification of regional strengths of the country using LQ (threshold level used for selection of priority sectors is $L Q>1.5$ ) was main outcome of engagement of external experts. The Analytical team has supplemented this deliverable with five ranking lists of all NACE 3-digit active sectors-groups for four statistical regions and for Serbia total, using Compromise Programming Ideal Point Method.

Discussions on procedures of mapping of economic, innovative and scientific potentials which should serve as a prerequisite for efficient specialization in regions of Serbia could be summarized into several factors:

(1) Selectivity and coverage: the use of LQ to identify priority sectors results in just a few NACE 3-digit sector groups that meet the predefined criterion (LC> 1.5) and this is a desirable method if the objective is to identify only a 
limited number of sectors that meet the criteria. On the other hand, the use of the MCDM method resulted in a ranking list of all NACE 3-digit sector groups, giving greater scope for a broader approach to identifying regional priorities. Coverage in case of using MCDM method is comprehensive. Information is available for all NACE sectors in the regions. In addition, this information is also available at national level which can be very important information for decision makers in the field of research and innovation policies;

(2) Inclusiveness: In the process of selecting potential regional priorities, using $L Q$, identifies those potential sectors that meet only one of the three criteria. It is sufficient to satisfy one of the following three criteria: economic, innovative or scientific potential. The use of MCDM implies fulfilment of all three criteria, i.e. potential priority regions must meet all three criteria of economic, innovation and scientific potential;

(3) Simplicity: Both methods for identifying potential regional priorities are relatively straightforward and simple; nevertheless, the use of the 0-1 excel tool developed to implement the LQ approach could be questionable for most decision makers, while the use of the MCDM method could be more evident having geometrical distance as aggregate measure for all implemented indicators;

(4) Completeness: Considering the disadvantages and advantages of both methods, it is logical to combine both methods, since both selectivity and inclusivity are equally important. As mentioned above, the use of the LQ method is very useful in order to select a limited number of priorities, while the MCDM method is ideal for consolidating all available indicators into one indicator: forming a ranking list of all NACE sector groups in the region or country, with the precise position of each group.

Smart Specialization Strategy of the Republic of Serbia is finalized in 2019. and it is due to be adopted soon in early 2020. Although quantitative analysis, conducted in the first stage of the process, provided the core content for the S3, after the EDP process, final list of the priority domains for Smart Specialization in Serbia has been changed, encompassing (1) Food for future (2) Information Communication Technologies (3) Machinery and production processes of the future and 4) Creative industries.

\section{References}

Aghion, P., David, P.A. and Foray, D. (2009). Science, technology and innovation for economic growth: Linking policy research and practice in 'STIG Systems'. Research Policy 38 (2009) 681-693 
Aprahamian, A. and Guilherme Correa P. (2015). Smart specialization in Croatia: inputs from trade, innovation, and productivity analysis. Directions in development; countries and regions. Washington, D.C.: World Bank Group.

Burger A. and Kotnik P. (2014). "Professional analysis as the basis for the Smart Specialisation Strategy", April 2014

Croatian Smart Specialisation Strategy 2016.-2020. (2016) Retrieved from: http://s3platform.jrc.ec.europa.eu/documents/20182/222782/strategy_EN.pdf/e0 e7a3d7-a3b9-4240-a651-a3f6bfaaf10e

Czyzewska-Misztal D. and Golejewska A. (2016). The least innovative regions in Poland in the process of Smart Specialization, Optimum Studia Ekonomiczne NR 5 (83), 123-137

European Commission (2010). Regional Policy Contributing to Smart Growth in Europe 2020, COM (2010) 553 final

European Commission (2012). Guide to Research and Innovation Strategies for Smart Specialisations (RIS3), retrieved from: http://s3platform.jrc.ec.europa.eu/ documents/20182/84453/RIS3+Guide.pdf/fceb8c58-73a9-4863 8107-752aef 77e $7 \mathrm{~b} 4$

European Commission (2015) Communication from the Commission to the EP, the Council, the EESC and the CR. EU Enlargement Strategy. COM(2015) 611 final

European Commission (2017). Investing in a smart, innovative and sustainable Industry - A renewed EU Industrial Policy Strategy, $\operatorname{COM(2017)~} 479$ final, Brussels, 13.9.2017

European Commission (2018) A Credible Enlargement Perspective for and Enhanced EU Engagement with the Western Balkans, Communication to the European Parliament, the Council, the European Economic and Social Committee and the Committee of the Regions, COM(2018) 65 final, 2018.

European Parliament and the Council (2014) Regulation (EU) N²31/2014 of the EP and of the Council of $11 / 03 / 2014$ - OJ L 77/11 of 15.03.2014

Foray, D., David, P.A. \& Hall, B. (2009). Smart Specialisation - The Concept. Knowledge Economists Policy Brief no. 9, Knowledge for Growth Expert Group

Gulc A. (2015). Analysis of methodological approach to identify smart specialization on the example of Polish regions, Procedia - Social and Behavioral Sciences 213 (2015) 817-823 http://ec.europa.eu/regional_policy/sources/docgener/presenta/ smart_specialisation/smart_ris3_2012.pdf

JASPERS/ARUP (2013) Knowledge Économy-R\&D/Innovation Analysis and Evidence Base of the R\&D\&I Market in Romania, Recommendations Report

JRC and IWB (2017). Smart Specialisation \& Organisational Development: Roadmap 2017-2018 for the pilot project with Serbia. Internal working document

Kociuba D. (2015). Regioanl Innovation Strategy - from design to implementation. Lubeslskie Voivodship Case Study, Barometr Regionalny, 15 (2), 99-114

Kroll, H., Schnabl, E., \& Horvat, D. (2017). Mapping of economic, innovative and scientific potential in Serbia. Karlsruhe: Fraunhofer ISI.

Matusiak M., Kleibrink A. (ed.) (2018) Supporting an Innovation Agenda for the Western Balkans: Tools and Methodologies, Publications Office of the European Union, Luxembourg.

Radosevic S., Spiesberger M., Stanionyte, L, Gnamus, A., Yegorov, I. and Josimovski S. (2016) The Role of Smart Specialisation in the EU Enlargement and

Industrija, Vol.48, No.2, 2020 
Neighbourhood Policies, Danube-INCO.NET, This project funded from the European Union's Seventh Framework Programme.

Region Värmland (2015) Värmland's Research and Innovation Strategy for Smart Specialisation 2015-2020, retrieved from: http://www.regionvarmland.se/wpcontent/uploads/2016/02/VRIS3.pdf

S3 Platform (2012). Guide to Research and Innovation Strategies for Smart Specialisation (RIS3), May 2012

South-East Regional Development Agency (2017). The Smart Specialization Strategy of the South-East Development Region, Project co-financed from ERDF through ROP 2014-2020

Zeleny, M., (1976). The Theory of the Displaced Ideal. In Zeleny, M., (ed), Multiple Criteria Decision Making, Berlin-Kyoto, Springer-Verlag, 1976, pp.153-206

\section{Appendix I}

Table A1. Selection of NACE 3-digit level sectors-groups by regions, $L Q>1.5$

\begin{tabular}{|c|c|c|}
\hline No. & LQ>1.5 RS11 - Belgrade & $\begin{array}{l}\text { Indicator(s) for } \\
\text { selection }\end{array}$ \\
\hline 1 & C18.1 - Printing and service activities related to printing & SBS \\
\hline 2 & C26.2 - Manufacture of computers and peripheral equipment & SBS \\
\hline 3 & H49.3 - Other passenger land transport & LFS Employment \\
\hline 4 & $\begin{array}{l}\text { J58.1 - Publishing of books, periodicals and other publishing } \\
\text { activities }\end{array}$ & Innovating Firms \\
\hline 5 & $\begin{array}{l}\text { J62.0 - Computer programming, consultancy and related } \\
\text { activities }\end{array}$ & Innovating Firms \\
\hline 6 & K64.1 - Monetary intermediation & LFS Employment \\
\hline 7 & $\begin{array}{l}\text { M72.1 - Research and experimental development on natural } \\
\text { sciences and engineering }\end{array}$ & Innovating Firms \\
\hline 8 & P85.4 - Higher education & LFS Employment \\
\hline No. & $\begin{array}{l}\text { LQ>1.5 } \\
\text { RS12 - Vojvodina }\end{array}$ & $\begin{array}{l}\text { Indicator(s) for } \\
\text { selection }\end{array}$ \\
\hline 1 & A1.1 - Growing of non-perennial crops & $\begin{array}{l}\text { LFS Employment + } \\
\text { Exports + Innovating } \\
\text { Firms }\end{array}$ \\
\hline 2 & $\begin{array}{l}\text { C10.1 - Processing and preserving of meat and production of } \\
\text { meat products }\end{array}$ & SBS \\
\hline 3 & C19.2 - Manufacture of refined petroleum products & SBS \\
\hline 4 & $\begin{array}{l}\text { C20.1 - Manufacture of basic chemicals, fertilizers and nitrogen } \\
\text { compounds, plastics and synthetic rubber in primary forms }\end{array}$ & Exports \\
\hline 5 & C22.2 - Manufacture of plastics products & SBS \\
\hline 6 & C29.3 - Manufacture of parts and accessories for motor vehicles & SBS \\
\hline 7 & C26.3 - Manufacture of communication equipment & Patents \\
\hline 8 & C28.3 - Manufacture of agricultural and forestry machinery & Patents \\
\hline No. & $\begin{array}{l}\text { LQ>1.5 } \\
\text { RS12 - Šumadija and Western Serbia }\end{array}$ & $\begin{array}{l}\text { Indicator(s) } \\
\text { selection }\end{array}$ \\
\hline 1 & A1.2 - Growing of perennial crops & LFS Employment \\
\hline 2 & A1.4 - Animal production & LFS Employment \\
\hline 3 & A1.5 - Mixed farming & LFS Employment \\
\hline
\end{tabular}




\begin{tabular}{|c|c|c|}
\hline 4 & C10.3 - Processing and preserving of fruit and vegetables & Innovating Firms \\
\hline 5 & C14.1 - Manufacture of wearing apparel, except fur apparel & $\begin{array}{l}\text { Innovating Firms + } \\
\text { SBS }\end{array}$ \\
\hline 6 & C16.1 - Sawmilling and planning of wood & SBS \\
\hline 7 & C22.2 - Manufacture of plastics products & $\begin{array}{l}\text { LFS Employment + } \\
\text { Innovating Firms }\end{array}$ \\
\hline 8 & C25.4 - Manufacture of weapons and ammunition & SBS \\
\hline 9 & C29.1 - Manufacture of motor vehicles & $\begin{array}{l}\text { LFS Employment + } \\
\text { Exports + SBS }\end{array}$ \\
\hline 10 & C29.3 - Manufacture of parts and accessories for motor vehicles & SBS \\
\hline 11 & C31.0 - Manufacture of furniture & $\begin{array}{l}\text { LFS Employment + } \\
\text { Innovating Firms }\end{array}$ \\
\hline 12 & G46.9 - Non-specialized wholesale trade & Innovating Firms \\
\hline 13 & C28.9 - Manufacture of other special-purpose machinery & Patents \\
\hline No. & $\begin{array}{l}\text { LQ>1.5 } \\
\text { RS22 - Southern and Eastern Serbia }\end{array}$ & $\begin{array}{l}\text { Indicator(s) } \\
\text { selection }\end{array}$ \\
\hline 1 & C22.1 - Manufacture of rubber products & SBS \\
\hline 2 & C24.1 - Manufacture of basic iron and steel and of ferro-alloys & SBS \\
\hline 3 & D35.1 - Electric power generation, transmission and distribution & LFS Employment \\
\hline 4 & $\begin{array}{l}\text { T98.1 - Undifferentiated goods-producing activities of private } \\
\text { households for own use }\end{array}$ & LFS Employment \\
\hline 5 & $\begin{array}{l}\text { C32.5 - Manufacture of medical and dental instruments and } \\
\text { supplies }\end{array}$ & Patents \\
\hline
\end{tabular}

Source: Analytical team, internal working documents, 2017-2018, based on analytical tool as source (Kroll et al. 2017).

Industrija, Vol.48, No.2, 2020 